\title{
How Elite Configurations Explain Shifts from Democracy to Authoritarian or Totalitarian Regimes: Turkey as a Case Study
}

\author{
Michael Gerlich \\ Anglia Ruskin University, Cambridge, UK \\ Email: michael.gerlich@cantab.net
}

How to cite this paper: Gerlich, M. (2021). How Elite Configurations Explain Shifts from Democracy to Authoritarian or Totalitarian Regimes: Turkey as a Case Study. Open Journal of Political Science, 11, 273300.

https://doi.org/10.4236/ojps.2021.112019

Received: March 17, 2021

Accepted: April 16, 2021

Published: April 19, 2021

Copyright $\odot 2021$ by author(s) and Scientific Research Publishing Inc. This work is licensed under the Creative Commons Attribution International License (CC BY 4.0).

http://creativecommons.org/licenses/by/4.0/

\begin{abstract}
Attempting to predicting the formation of particular types of governance structures has been one of the central tasks of sociologists and political scientists. John Higley and Michael Burton argued that the configuration of elite groups in a society is an important predictor of the governance structure that develops in that society. The Higley-Burton theory outlines several ways in which the configuration of elites can predict the transformation of governance structures, from authoritarian regimes to liberal democracies. In the current research, this previous theoretical work is extended by articulating a route by which societies can go the other way-from democracy to an authoritarian regime. Turkey is being used as a contemporary case study to show how shifts elite configurations in a democracy can lead to authoritarian regime. A five-step process for this transformation is outlined. The steps in this model for one route of moving from an unstable democracy towards autocracy or dictatorship can be summarized as follows: 1) Political success by one group or faction. 2) Establishment of an inner circle and consolidation of power. 3) Replacement of the inner circle with weaker members who can be controlled. 4) Self-isolation of the leader. 5) Government control of opposition and suppression of dissent.
\end{abstract}

\section{Keywords}

Elite Configuration, Democracy, Turkey, Political Elites, Government, Elite Theory, Higley \& Burton

\section{Introduction}

Explaining and predicting the formation of particular forms of government, such as democracies, authoritarian regimes, and totalitarian regimes and the 
transitions from one to another has been a central task of sociology and political sciences. A large amount of research has focused on this area, from a wide range of domains, and using various theoretical orientations (Bian, Shu, \& Logan 2001; Casper, 1995; Gerschewski, 2013; Higley, 2018a, 2018b; Higley \& Burton, 1989, 2006; Linz, 2000; Linz \& Stepan, 1996; Pérez-Liñán \& Mainwaring, 2013; Shorten 2012). Some researchers, such as Linz (Linz, 1990, 2000; Linz \& Stepan, 1996), have pointed to the importance of the features of various governance structures (parliamentary systems, presidential systems, and others) and suggested that some are less stable than others and more likely to result in one type of regime over others. They suggested that more stable systems may undergo a transition from one type of regime to another less often and further emphasize that a prior form of regime influences subsequent regimes (Linz \& Stepan, 1996). Other researchers have emphasized the role of extra-governmental institutions, such as religious organizations or the military, in influencing the regime that develops and the transition between different regimes (Casper, 1995). Still others, such as Shorten (2012), underscored the role of ideology in building political support for particular forms of governance.

The role of elites in the construction and maintenance of various forms of governance has emerged as a useful method to explain the shifting forms of government. Elites are individuals who have the power to affect political outcomes substantially as a result of their disproportionate access to resources (Bourdieu, 1984, 1986; Higley, 2009; Lopez, 2013; Wedel, 2009, 2017). These resources can be political capital as a result of an important position in an organization that itself has power (Mills, 1956); or it can come from other sources, such as economic capital (Kahn, 2012), knowledge capital (Kahn, 2012), social capital (Wedel, 2017), or cultural capital (Bourdieu, 1984). Higley and Burton $(1989,2006)$ and others (Lopez, 2013) argue that the way elite groups are configured, can be an important predictor of the governance structure that develops. They have proposed that elite configurations predict the structure of governance, but they have outlined several routes by which governance structures transform into liberal democracies (Higley and Burton, 2006).

Higley and Burton's (2006) conception of elite configurations and the transitions in configurations that can support liberal democracies is useful in that it helps to link what we know from the elite literature-that informal networks of powerful individuals exist and have influence on governance decisions (Wedel, $2009,2017)$ - to how we understand the transitions to the various forms of governance. It is especially useful in explaining how non-democratic forms of government shift towards democracy. In this article, the concepts presented by Higley and Burton $(1989,2006)$ are used to explore a possible route in the opposite direction-from democracy towards dictatorship, and Turkey is used to illustrate this proposed transition.

In the recent past, Turkey was seen as having a uniquely strong democracy in its region, and there was optimism that Turkey could be a democratic archetype 
for other Muslim majority countries (Somer, 2016b, 2019). More recently, there has been a clear shift away from democracy (Cagaptay, 2017, 2018; Diamond, 2015; Esen \& Gumuscu, 2016; Önis, 2015; Özbudun, 2014, 2015; Somer, 2016b) into what can be called "competitive authoritarianism" (Esen \& Gumuscu, 2016). While several others have described the decline of Turkey's democracy, and even explained it in terms of powerful individuals (Somer, 2016b, 2019; Cagaptay, 2017) there has not yet been an analysis of this shift away from democracy using an elite theory perspective. The gradual but intensifying shift towards authoritarianism can be explained by understanding the elite configuration.

This paper argues, consistent with previous literature, that multiple elite groups are required for a democracy to function (Higley \& Burton, 1989, 2006). It begins by reviewing the literature that establishes the existence of elite groups and presents their function in the governance of a state. It then reviews different proposed configurations for elite groups (consensually united, ideologically united, and disunited elite groups), and connects these configurations to a number of different types of governance regimes (stable democracies, unstable democracies, authoritarian regimes, and dictatorships). Next, a review of several existing models for how countries come to form consensually united regimes is provided. Finally, the paper proposes a five-step model for the transition from an unstable democracy to an authoritarian regime and a dictatorship and uses Turkey to illustrate this process. It proposes that first, in a democracy one elite group or faction obtains political success and establishes an inner circle and consolidates power. The leader of the elite group then replaces members of the inner circle with weaker members who are more easily controlled, which secures the leader's own power. Subsequently, the leader ends up isolating themselves and becomes increasingly insecure. Finally, the leader increasingly tries to ensure control of the political opposition and suppresses dissent.

\section{The Influence and Function of Elites}

This paper uses as its foundation literature on political elites (Bourdieu, 1984; Domhoff, 2017; Heilbron et al., 2017; Higley, 2018a; Higley \& Burton, 2006; Kahn, 2012; Lopez, 2013; Wedel, 2009, 2017). Following Best \& Higley (2018), elites are defined as "individuals and small, relatively cohesive and stable groups with major decisional power". Elite theory begins with the assumption that elites influence the governance and economic outcomes in most-if not all-contemporary societies (Higley \& Burton, 2006: p. 5; Lopez, 2013; Mosca, 1960; Pareto, 1935), echoing Michels (1962) “iron law of the oligarchy." Based on classic work by Pareto (1935), Mosca (1960), Michels (1962), and Keller (1963), Higley and Burton (2006) and others (Higley, 2018a) go so far as to argue that the unequal distribution of power in a relatively small group of elites might be inevitable. Higley and Burton (2006) argue that societies, once they consist of more than a handful of individuals, must organize themselves to function in order to make decisions about the actions that they will take, their policies, and about how re- 
sources will be allocated, among others. These decisions are most efficiently made by a small number of people rather than by including everyone; thus, a hierarchical system must be established. As these individuals have more access to influence over the decisions that are made, they have more power in the organization, and this results in a set of elites in the organization. In this way, Higley and Burton (2006) argue that elites must exist in organizations that have more than a handful of people. They further contend that people with power or influence over decisions in societal and governmental organizations also have disproportionate power over decisions that happen in society more generally. This creates an embedded set of elites for any society that has organizations, and people at the top of important societal organizations create at least one set of elites. Examples of organizations that commonly confer power to those in high positions include governance, military, and religious organizations (Lopez, 2013). Further research has illuminated the various other ways that individuals can obtain disproportionate power in a society, such as by obtaining economic power, cultural capital, power from knowledge, or social power from being associated with other elites (Kahn, 2012). More recent theories have questioned whether the power of modern elites primarily originates in organizational power structures (Wedel, 2017), but the proposition that elites are important in complex human societies has remained relatively uncontroversial.

Behavior and activities of political elites in general are influenced by two opposing maxims. Political interests are being formulated by the political elites; while at the same time, decisions need to be supported by majorities as well as on the ability of leading influencers on political opinions to cooperate and to overcome conflicts. "The function of elites (in pluralistic systems) therefore is not only to articulate, aggregate and represent interests but to balance these interests. ... [Elites] are individual agents as well as the instance of regulation of cooperation.” (Herzog, 1982) Elites also play a function in the maintenance of the governance of a state and the maintenance of liberal democracies. Elites come together to form coalitions, and these serve to represent a diverse set of societal interests, including political interests, economic interests, and social interests (Wedel, 2017). When no single elite group is dominant over the others, this variety of elite groups can help to regulate and temper each other to prevent any one group from becoming too powerful (Higley, 2018a; Higley \& Burton, 2006). They can ensure that a state functions in such a way as to represent a variety of people. Higley and Burton (2006) argue, and it is argued here, that cooperation from elite groups is required for liberal democracies; without multiple functioning and diversified elite groups, stable democracies cannot thrive. Moreover, the way elites interact with each other is also important: whether elite groups function to support liberal democracies or undermine them depends at least to some extent on the configuration of these groups.

\section{Routes to Consensual Unity and Democracy}

In addition to proposing that consensual unity is a requirement of stable demo- 
cracies, Higley and Burton (2006) have proposed three ways that elites in a particular society become consensually united: through settlement, convergence, or as a result of consensual unity being transferred to a colony.

\subsection{Settlement}

The first route to consensual unity of elites is through a process called elite settlement (Higley and Burton 2006). Elite settlement refers to the formation of consensually united elites after, "suddenly and deliberately reorganize their relations by negotiating compromises on their most basic disagreements" (Higley \& Burton, 1989: p. 21). This typically comes after some threat to the elite factions-either from an outside force or from the public. For example, a civil war can prompt settlement; when the factions come together at the end of the war, they may come to agree on the rules that should govern their behavior (Higley \& Burton, 2006: p. 64). This is because each group comes to understand that through the agreement, the outcomes for their faction may be better than if there was no agreement. While the cooperation with the other elite groups may mean that their group occasionally loses power, the faction sees that unity may be the best way to achieve their goals in the long run.

One example is the settlement that occurred in the United Kingdom in the late 1600s. There were three main political factions: the two main political parties, the Tories and the Whigs, and the King and his allies. Very briefly, conflict over religious freedoms and rights between the two political parties and the King led to several civil wars. At the end of the wars, the Tories and the Whigs came together to write the constitution, which specified how power should be split, and the ways that the political parties could interact with each other. It specified a number of rules that governed how the political parties could interact with each other and limited the influence of the monarch. This ultimately resulted in a settlement between the two main parties that allowed them to achieve consensual unity and resulted in a stable democracy for several hundred years.

\subsection{Convergence}

Another process that leads to consensual unity of elite groups is called convergence (Higley \& Burton, 1989). This occurs in conditions where there already is a democracy, but it is unstable, and it describes the process of political rivals coming together to compete against one other dominant group. This process occurs in two steps; in the first step, political rivals that have traditionally conflicted, come together to form a coalition to dominate the political landscape, and they achieve significant political success in this way. As a result, the opponents to this political group slowly adapt the ideological stances of the dominant group in order to continue to be able to compete successfully in political competitions themselves. In this way, the values of these opponents slowly begin to converge on the values of the dominant groups. Thus, elite political groups eventually come to agree on a set of values or political structures not through an 
explicit agreement, but a convergence of values over time as a result of a desire to compete more effectively (Higley \& Burton, 1989).

Higley and Burton (1989) propose that it was this process that led to the stable democracies that are now evident in France and Italy throughout the 1990s. For example, in France, the political landscape was dominated for a considerable period by the French Socialists, whom some saw as radical. To compete, the French right-wing parties formed coalitions and eventually came to dominate French politics. The Socialists, therefore, altered their ideologies to become less radical and more politically palatable to the French public. Eventually both sides converged on a set of values that they shared, and thus created the kind of stable, liberal democracy that currently exists in France.

\subsection{Colonial Origins}

The last process that Higley and Burton (2006) suggest for creating consensual unity is through colonization. For example, if one country that has a consensually united elite themselves colonizes another country, those norms are then passed on and established in the colonized country. They argue that Canada's consensually united elite, and stable democratic system, was the result of the British colonial history that provided the country's foundation.

\section{A Route to Power That Reinforces Instability}

The previous section describes the three processes that can create consensually united elite groups. Higley and Burton (2006) suggest that it is consensual unity that is the only elite configuration that can support the formation of stable, liberal democracies. However, they also argue that consensual unity is a relatively rare elite configuration, and elite disunity and ideological unity are much more common. Disunited elites tend to lead to unstable democracies and authoritarian regimes, and ideologically united elites tend to create dictatorships (Higley \& Burton, 2006). However, what are the routes to these elite configurations? This next section proposes one possible route ${ }^{1}$ that can transform a country from an unstable democracy into an authoritarian regime, and ultimately into a dictatorship.

First, an elite group dominates the others, with one strong leader coming to power by democratic means. The elite group may be made of a few close political connections or allies (Mahdavi \& Ishiyama, 2017). Once in power, the leader centralizes the distribution of elites to positions of power and may replace all positions of influence with strong, closely related friends and family members (Lewis, 2002; Urban, 1989). This replacement with individuals close to the leader is a way for them to ensure that they can trust those individuals to work on their behalf and not to challenge their leadership position. These individuals form what can be described as an "inner circle" of power.

The inner-circle then works to consolidate its power. Linz and Stepan (1996)

${ }^{1}$ Of course, not all routes away from democratization follow this model. 
identify five characteristics of a functioning democracy: a free and lively society in which people can create associations, societies, monitor the state and deliver political alternatives; a relatively independent political society, in which political groups compete for a legitimate right to compete and that society is valued; a legal system that can guarantee citizens freedom and ability to associate freely; a functional state bureaucracy; and an "institutionalized economic society" or a set of norms, institutions and regulations that govern how the state and economy interact. These five characteristics are necessary for democracy because they ensure that the power can be legitimately contested and that it can transition away from a governing group to another competing political group, and they enable citizens to undertake actions that constitute challenges to those in power (Linz \& Stepan, 1996).

A government can consolidate its own power in a democratic context by undermining these characteristics. This can be done in a number of ways, including undermining civil society by persecuting members of the media or civil society groups, intimidating or persecuting political opponents, influencing the legal system to reduce the protection of civil rights, or by seizing power of economic interests. In this way, they work to reduce or eliminate the influence and power of competing elite groups (Kendall-Taylor, Frantz, \& Wright, 2017).

Eventually, the faction is established in their position and does not face significant threats to their power from external elite groups. Instead, the biggest threats to a leader's power come from those who are closest to them-those in the inner circle (Kendall-Taylor et al., 2017; Mahdavi \& Ishiyama, 2017), and the leader may begin to fear the power of those who are closest to them. The leader may then seek to replace, one by one, all of the members in the inner circle with other, weaker individuals who function as puppets (Lewis, 2002; Mahdavi \& Ishiyama, 2017). By ensuring that the others in the inner circle are weaker, the leader can maintain their control over the other members of the inner circle. Eventually all that remains of the members of the leader's inner circle are weak individuals that can be controlled by the leader (Lewis, 2002). At this point, no one is left who can influence or temper the power of the leader because the other elites have been minimized.

The result is a leader that is isolated, and at this point, there is a risk of the country falling into a dictatorship. As the leader is now isolated, they may become afraid of a political challenge to their position or a coup. They may engage to a greater extent in government control, suppression of the opposition, and the use police force to control perceived political opponents and other elites (Kendall-Taylor et al., 2017). Political isolation creates a further increased risk of economic isolation, resulting in reduced prosperity of the nation, leading to a suffering and unhappy population (Tang, Huhe, \& Zhou, 2015). An unhappy population leads to an increased threat of challenges to the leader. At this point, the leader increases suppression to curb the increasing threats, and a cycle is created where increasing force must be used to control the population.

Thus, the steps in this model for one route of moving from an unstable de- 
mocracy towards a dictatorship can be summarized as follows:

1) Political success by one group or faction.

2) Establishment of an inner circle and consolidation of power.

3) Replacement of the inner circle with weaker members who can be controlled.

4) Self-isolation of the leader.

5) Government control of opposition and suppression of dissent.

\section{Countries at Risk of a Route to Instability}

Some countries may be particularly at risk of transforming into authoritarian regimes or dictatorships as described above, including transitioning or developing countries or countries with newly established democracies. In these countries, the parliament may not have adequate influence to balance that of the ruling party or leader, which means that there may be less structure in the government system to prevent certain elite groups (those elected to form government or the executive) from obtaining disproportionate power (Keil, 2018). These countries may be at risk because there is less of a consensus on values (Higley \& Burton, 2006).

Countries with a breakdown of political structures are also at risk (Higley \& Burton, 2006). This includes countries that have experienced long wars, or a breakdown in the political structure (such as the breakdown of communism in post-soviet societies; Lazic and Pesic 2018). In these countries, elite groups may have such a long history of conflict that it may be impossible to see each other as collaborators. This may prevent the structural integration that Higley and Burton (2006) argue is necessary for a consensually united elite. It also may hinder an elite group from considering government opposition as an important political structure, and instead, see it as a threat. This would make it difficult to achieve the kind of values consensus that Higley and Burton (2006) outline.

Several countries may currently be considered on a path towards increasing instability. Keil (2018) has described how Kosovo, Macedonia, Montenegro, and Serbia each serve as examples in which particular political elites have dominated political systems, inserted themselves in leadership, and have obtained disproportionate power and influence over social and economic systems, such as their respective judiciaries and media organizations. Keil (2018) asserts that the result is increasingly a retreat into authoritarianism. Džankić (2018) has similarly noted a return to authoritarianism in Bosnia and Herzegovina, as have Esen and Gumuscu (2016) for Hungary.

\section{The Case Study of Turkey}

In order to understand the role of elite structures and powerful and influential individuals in defining a governance structure, it is essential to launch an inquiry into the interactions of various elite groups organizations, state institutions, and actors. Indeed, the power elite plays an instrumental role in shaping the gover- 
nance systems, and the decisions of the elite are influenced by their vested interests, cultural and ethnic affiliations and other factors. (Highley and Burton, 2006). In the recent past, Turkey was seen as having a uniquely strong democracy in its region, and there was optimism that Turkey could be a democratic archetype for other Muslim majority countries (Somer, 2016a, 2019). More recently, there has been a clear shift away from democracy (Cagaptay, 2017, 2018; Diamond, 2015; Esen \& Gumuscu, 2016; Önis, 2015; Özbudun, 2014, 2015; Somer, 2016 b) into what can be called "competitive authoritarianism" (Esen \& Gumus$\mathrm{cu}$, 2016). Therefore, Turkey represents a contemporary case of a transition process from democracy to autocracy and was therefore chosen in this research. This section will explore the influence and role of the elite structures and groups in the case study of Turkey's shift towards a dictatorship or authoritarianism from democracy.

Higley and Burton (2006) have proposed that the configurations of elite groups are a significant predictor of the governance structure that takes shape within a state. They argue that elite configurations allow researchers and historians a deeper understanding of the formation of the governance structure, and they put forward various routes that map the transformation of governance structures towards liberal democratic systems (Higley \& Burton 2006).

This inquiry requires an in-depth and detailed understanding of the political transitions and evolutions that took place in Turkey in order to understand the emergence and inclinations of the various elite groups and state institutions that exert influence. It is crucial to understand the formation and functioning of elite groups across Turkey and their existence within the structure of Turkish state governance. In this section, we will attempt to understand the configurations of various elite groups, as proposed by Higley and Burton (2006), based on their ideological unions, rivalries and disagreements. Understanding the historical background will allow a deeper understanding of elite configuration and populism that exists within Turkey (Barr, 2009).

\subsection{Understanding Turkey's Political Evolution}

I will use the proposed five-step model to map out Turkey's transition towards authoritarianism from a liberal democratic structure. We will elaborate on each of the five steps with references to governance changes, exclusion of certain elite groups and ethnicities, the consolidation of power in a carefully selected inner-circle, suppression of dissent and exerting control over the opposition.

As we explore elite configuration and populism in the context of Turkey, we come across various frameworks that have aided in identifying the major themes and shifts that marked the evolution of modern Turkish ideologies and political systems. The Ottoman Empire left Turkey with political fragmentation and a sociocultural divide that allowed the ruling elite to control the pivot in a culturally and ethnically diverse periphery.

In this article, Turkey is used as a contemporary example to illustrate how this 
process can take effect. In the past decade, Turkey has undergone a number of political transformations and events that have resulted in what most commentators agree has been a breakdown in democracy and a slide into a dictatorship, including constitutional changes that have consolidated power in the presidential role and increasing power over the central bank, which ultimately culminating in a failed coup in 2016 (Özbudun, 2014, 2015; Diamond, 2015; Önis, 2015; Esen \& Gumuscu, 2016; Somer, 2016b; Cagaptay, 2017, 2018; Freedom House, 2018; Picarella, 2018; Somer, 2019). Freedom House, a non-profit organization that ranks how free citizens of various countries are, has reflected this slide into authoritarianism in their annual rankings. In 2018 they ranked Turkey as "unfree" for the first time since the 1980s (Freedom House, 2018).

This stands in contrast to its situation in the mid-2000s when Turkey was largely praised for building a strong, secular democracy in a Muslim majority state (Somer, 2019). At that time, several commentators were optimistic about the ability of Turkey to maintain its democracy (Yavuz, 2009). About Turkey's democratic institutions, Kinzer (2008: p. 13-14) said, Turks have at long last begun winning the civic revolution they have been waging for decades. Turkey's democratic institutions have proven strong enough to contain and guide this revolution, allowing it to proceed peacefully and within the bounds of law.

The increasing power of the Turkish president and the transformation into an authoritarian regime prompts the question: what caused this transition out of democracy? The question is particularly relevant given that Turkey did not demonstrate the factors that have contributed to the inability of other states to consolidate their democracy, such as poor economic performance (until recently Turkey has had relatively stable economic growth) or a weak state (Esen \& Gumuscu, 2016). Scholars have explained this transformation in terms of a number of factors, focusing on the polarization of the public, and the systematic deterioration of democratic structures such as the judiciary and the media (Esen \& Gumuscu, 2016; Somer, 2019). These explanations are useful, but they have missed the important reconfiguration in Turkey of a somewhat united elite into a disunited one. In this section, the shift from a democracy to an authoritarian regime is explained in terms of the configuration of elites and the five-step process outlined in the previous section.

1) Political success by one group or faction

During Ottoman rule, the centre was controlled by the imperial family and its ruling elite, and later under Republican rule, the centre shifted towards the "quasi-autonomous" bureaucracy, which was dominated by the alliance between the judiciary, military and large state-reliant corporations and businesses, the intellectual and academic committee, and mainstream media. The periphery shifted towards a diverse blend of regional, social, religious, ideological and traditional ethnic groups that were earlier systematically distanced from power-exerting institutions that defined state governance. It can be argued that as the AKP consolidated its control over Turkey, the exclusion of various religious and ethnic 
groups came to an end. The centre can be understood as a coherent and nationalist elite structure that represents and safeguards the state (Çarkoğlu, 2012a).

During the early Republican rule, Turkey was gripped under the tightened control of state institutions and apparatus, and the centre underwent a robust Westernization agenda with a top-down modernization of state institutions. Naturally, this aggravated the alienation and exclusion of the conservative and traditionalist ethnic peripheral communities. In Turkey, the centre has been traditionally dependent on the support of urban groups and masses who are highly educated, less inclined towards religious ideologies and feature lesser concentrations of ethnic minorities. The peripheral constituencies, on the other hand, have been dominated by religious and rural Muslims who lack higher education and feature greater concentrations of ethnic minorities (Çarkoğlu, 2012a; Turk, 2014).

In order to examine the change in an elite configuration in Turkey, we must reflect on the framework of "centre-periphery cleavage" that exists in Turkish history and politics. It allows us to understand the divide amongst the Turkish masses based on ideologies and political inclination. For instance, centrist communities hold secular beliefs and resonate with leftist politics, while the religious and traditionalist peripheral masses strongly associated with rightist politics (Çarkoğlu, 2012a).

The National Outlook, or Milli Görüş, spearheaded by Necemettin Erbakan, was the most vociferous and loudest populist movement in Turkey, and it put forward an antagonistic ideology that highlighted the imperialistic, materialistic and secular agendas of the "West" that sought to harm the oppressed, morally upright and "abstemious" communities of Muslims (Hadiz, 2016). The populist movement encouraged the establishment of a just order to eliminate the dominance of the West, not just in Turkey but throughout the Muslim community. The National Outlook comprised of ideological themes from the Ottoman and Republica era and made ideological references that will nostalgic of the glories cemented by the Ottoman Empire (Atacan, 2005). It was an Islamist political movement that opposed the control of the elites of the centre in Turkey. Its fight was not just against the ruling elite and political party, but in fact, it was against Western dominance, and they considered the ruling elites to the local facilitators and collaborators of the Western dominance that was imposed on Turkey against the will of the masses (Turk, 2014).

Recep Tayyip Erdoğan came to power in 2002 as the leader of the Justice and Development Party. This party had previously been a political outsider. However, they were elected to power after having formed a coalition with a variety of other disparate parties that managed to cut across class and ideologies. The timing was also right: the electorate, tired of the politics of the previous parties and suffering from an economic recession, saw the new party as an opportunity for wide-spread changes in political and economic structures (Somer, 2019). In his rise, Erdoğan managed to make use of the political connections he had made as Mayor of Istanbul (Cagaptay, 2017). Thus he, and a number of other political 
elites managed to form a coalition that was able to challenge the established elites successfully and achieve political success. In this way, although it has fluctuated over the past few decades, Turkey experienced some degree of consensual unity. However, at the time of Erdoğan's election, there was a relative consensus about the appropriate political behavior and some degree of structural integration (Esen \& Gumuscu, 2016).

\section{2) Establishment of an inner circle and consolidation of power.}

It is important to the note that the majority of the key political figures in the incumbent ruling party, the AKP, began their political careers with the Milli Görüş movement. Incumbent Turkish President, Tayyip Erdogan held various significant positions in the Milli Görüş movement since 1976. Erdogan was also designated in the office of the mayor of Istanbul. Towards the late 1990s, Erdogan led a group of younger members of the Milli Görüş movement, and the youth distanced themselves from the traditional views of older Islamists. In 2001, the AKP, a new political faction, came into existence and in the aftermath of the 2002 general elections, the AKP consolidated power as a single-party government (Coşar \& Ozman, 2004).

Following his political success, Erdoğan worked to consolidate the power of his party and his own role through a number of reforms. Among the changes he made were reforms to reduce the influence of the military. He did this by enacting a number of legislative changes that served to increase the role of elected officials in making decisions that had traditionally been the role of the military (Esen \& Gumuscu, 2016). He also made it both illegal for the military to intervene in political matters and delegitimized it politically. Erdoğan's government also changed the structure of the National Security Council, and included a greater number of members who were not members of the military, and reduced the force of their decisions by making them merely recommendations (Esen \& Gumuscu, 2016). Further, military seats on other committees, such as the Radio and Television Supreme Council, were removed. Where before the military had been essentially able to veto elected officials (Freedom House, 2018), Erdoğan implemented a strong mandate to reduce these powers, and in so doing, consolidated his power (Esen \& Gumuscu, 2016).

He made similar decisions to undercut the strength of the judiciary. For one thing, he took a number of members of the military to trial using the legal system as a way to harass and intimidate members of the military in what were highly politicized trials that consistently violated the legal rights of those on trial (Esen \& Gumuscu, 2016). Due process was limited, and in some cases, evidence was fabricated (Levitsky \& Way, 2010a). After using the courts to harass political enemies, ultimately Erdoğan reformed the way they were structured so that they were less effective at challenging the government (Levitsky \& Way, 2010b). Further power was concentrated in the position of President in April 2017 through a referendum (Freedom House, 2018).

These reductions in the power of these institutions are important because the judiciary and especially the military, have traditionally housed some of Turkey's 
most powerful elites, and military elites have been a regulator of Turkey's politics throughout its history (Cagaptay, 2017). By reducing the power of the military to intervene, Erdoğan managed to undermine the power of this important elite group and increase his power. He was, therefore, able to beat other elite groups in the election and win political control, and also undermine their power in other domains. Further, since its election, his party has used the state-owned media and regulatory agencies to advance the parties own priorities; they have used legal action to reward supporters of the party and suppress those who oppose the party; and they have used public resources to enrich the party, improving its ability to compete in elections (Esen \& Gumuscu, 2016, 2017). Turkey is now a state in which, while there is competition for political power, that competition is increasingly unfair, and the playing field is very much tilted towards the AKP and Erdoğan (Esen \& Gumuscu, 2016, 2017; Somer, 2019).

Erdoğan continued to consolidate power by creating a close group of individuals that made up his inner circle. He ensured that his cabinet was filled with those who had been loyal to him in his rise to the position of president (Fanack, 2018; Horizon, 2018). In a criticism of Erdogan's inner circle, the former Foreign Minister of Turkey, and fellow party member Ahmet Davutoglu has said that Erdogan's inner circle "sees itself above the committees of our party and aims to rule the party like a parallel structure" (Gall, 2019: para. 13). These actions further served to allow the AKP and Erdoğan to consolidate and maintain power. In this way, Erdoğan undermined what values consensus existed in the political landscape before his party came to power, creating an increasingly disunited configuration of political elites.

Turkish and foreign political observers conclude that Recep Tayyip Erdogan's rise to power as the President of Turkey in August 2014 marked the beginning of the transformation in Turkey's political structure and elite configuration. The incumbent President not only regards himself as the head of state but also, as a guarantor of the will of the Turkish masses. There is a deepening and strengthening assertion in Turkish traditionalist and religious circles that the incumbent government, itself policies and the personality of President Erdogan are reflective of the political ideologies, identify and culture of the Turkish masses. Admirers and supporters of Erdogan also claimed that his rise to power has allowed Turkey to acknowledge, for the first time, the cultural and ethnic plurality of the Turkish population, as seen during the peace negotiations conducted with the proscribed Kurdistan Worker's Party (PKK) (Seufert, 2014).

Erdogan's "New Turkey" is claimed to have dismantled the political teachings and ideologies that were exercised by the old secular elites that subjugated and overruled the majority population with the support of the judiciary and the military. It is claimed that the new regime led by President Erdogan is democratic and culturally "authentic" (Seufert, 2014).

3) Replacement of the inner circle with weaker members who can be controlled. 
As we examine Erdogan's rise to power and his career in the AKP and earlier, we note that his political discourse and ideologies were focused on "democratization", which was interpreted by the Turkish masses as a struggle to understand and reflecting the will of the conservation majority against the control exercised by the Kemalist elite (Seufert, 2014). This antagonism towards the Kemalist elite and their power configuration structures contributed to Erdogan's popularity and aided him in amassing followers from ethnic groups, religiously inclined regions, disparate communities and even garnered him foreign support. In 2013, the clashes that resulted over the plans for the Gezi Park in Istanbul provided Erdogan with an opportunity to establish and instrumentalize his political discourse on democratization to legitimize his strategy of retaining and consolidating power. Foreign and Turkish observers argue that Erdogan has dismantled the decades-old political teachings and control exerted by military generals by instigating the masses against the influence of foreign powers over the Turkish government and state (Turk, 2014; Seufert, 2014). This strategy has allowed Erdogan to undertake authoritarian decisions, dismantle the agendas of the opposition, interfere in judicial matters under the pretext of defending the Turkish democratic system. At the end of March 2014, Erdogan introduced and intensified his rhetorical stance against foreign powers and their stooges before the municipal elections and during his presidential campaigns. Experts review that this rhetorical brand-marking allowed Erdogan to boost his followers and support. In the municipal elections, Erdogan's support was ranked at $43.39 \%$ and shortly after, in the presidential elections, this support rose to over $52 \%$. Erdogan was able to win over this support by uniting voters from various small-scale right-wing parties who did not allow their own candidates to compete. These parties include the Turkish nationalist Great Union Party (BBP), the Turkish-Islamist Felicity Party (SP), and the Kurdish-Islamist Free Cause Party (HudaPar) (Seufert, 2014).

More recently, there has been a significant reduction in the influence of the inner circle on Erdoğan's policy decisions. Many of those that originally formed the inner circle and were important influences on Erdoğan's decisions, including Yalcin Akdogan, Ilnur Cevik, Yigit Bulut, and Mustafa Varank, have all lost their sway in recent years (Horizon, 2018). In one example, Erdoğan appointed Berat Albayrak, his son-in-law, as the Minister of Finance in 2018, despite worsening economic issues and Albayrak's lack of qualifications for the position (Fanack, 2018). This appointment occurred in a cabinet shuffle that saw the ousting of Ahmet Davutoglu, a previously strong ally to Erdoğan. The move was largely seen as a way to ensure that Erdoğan can ensure that he has some control over the decisions that are made by the minister, and it was a move to ensure loyalty (Fanack, 2018). The replacement of inner circle members can also be seen in the abolishment of positions central to reigning in the president, including the removal of the vice-president position (MacDonald, 2018). Erdoğan has made further efforts to dominate institutions and neutralize strong elites within his party since the attempted coup in July 2016 (Kendall-Taylor et al., 2017). 


\section{4) Self-isolation of the leader.}

There is a wealth of academic literature that examines Turkey's shift towards authoritarianism, and semi-democratic rule. The transition towards authoritarianism is widely associated with the rise of the Justice and Development Party (AKP), the incumbent ruling party and its predominance in the governance structure and political configuration of the Turkish regime (Müftüler-Baç \& Fuat Keyman, 2012; Musil, 2014). These studies regard authoritarianism as a form of resurgence or reinvention of the centuries' old, ingrained authoritarian characteristics of Turkey while emphasizing some new ideological traits that stemmed from the Islamic inclination of the ruling AKP, and the personality traits and agendas of President Erdogan. A growing body of research explores the political transition of Turkey and concludes that the country is experiencing a total democratic breakdown, and is marking a transition from a semi-democracy to a new form of political structuring that can be defined as competitive authoritarianism under the rule of a hegemonic political party (Somer, 2014; Esen \& Gumuscu, 2016). These analyses introduce us to various events and developments that allowed this political transition and changes in elite configuration, such as the dismantling of institutional checks on the executive power resting with the President, the erosion of differences between the ruling political party and state, governmental restrictions imposed on civic freedoms, and tilting the electoral environment to align it with the agendas of the ruling political party. As we explore Turkey's political transition towards authoritarianism, we come across various features and elements that reveal characteristics of the old authoritarian regime, semi-democracy political structure, and the teachings of the military and bureaucracy. The shift toward authoritarianism can be partially explained through the Islamic inclinations of the incumbent Turkish government and the charismatic personality of a populist leader, which has paved the way for the revival of long-standing authoritarian features and institutions with various new prerogatives and elements focused on Islamist ideologies.

While it may be too early to suggest that Turkey is a dictatorship, or that Erdoğan has become a dictator, his move away from traditional inner-circle allies seems to suggest increasing isolation and looks increasingly like a dictatorship (Cagaptay, 2017; Somer, 2019). Consistent with the proposed route to authoritarianism, the isolation of Erdoğan has come with an isolation of the economy, as his previous, investor-friendly inner circle has been removed systematically (Ant \& Hacaoglu, 2018). The result has been an increasingly poorly performing economy. Economic indicators suggest that Turkey's economic struggles will continue in the near future: inflation is on the rise, as is youth unemployment (MacDonald, 2018). The Lira has lost approximately $40 \%$ of its value in relation to the US Dollar, since the beginning of 2018 (Congressional Research Service, 2018), and many have described Turkey's economic situation as a crisis (Oyat, 2018; Taskinsoy, 2019) and the "worst economic downturn in its history" (Schanzer, Erdemir, \& Tahiroglu, 2019). Due to the poor economic outcomes, Erdoğan has extended his role to increase the influence that he has 
over the Central bank in order to prevent rising interest rates (Ant \& Hacaoglu, 2018). Thus, as predicted by the proposed model, poor economic outcomesarguably originating in the increasing control of a single leader-may lead to increased control by that leader. This increasing control has been met with various sanctions, and these have contributed to a worsening economic situation (Schanzer, Erdemir, \& Tahiroglu, 2019).

\section{5) Government control of opposition and suppression of dissent.}

In the case of Turkey, building pacts, forging compromises, and consensual rule-making has been weak and fairly non-existent between rival political actors and parties. It is yet another feature of the old authoritarian roots of Turkey, and it reveals the tendencies of the Turkish political elite to "dismiss" and deny the existence, representation, rights and legitimacy fo their rivals and the societal segments that they represent (Somer, 2016b). It is important to note that consensus-based democratic transformations have not been wholly absent; however, such periods of democratic changes were comparatively disruptive, short-lived and interrupted. In contrast, major changes and institutional transformations have always reflected the inclinations and preferences of hegemonic rulers and state actors through unilateral decisions. The rulers and political parties in power outlined new rules that excluded minorities and rivals, even though these new regulations were supposed to pro-democracy and inclusive of all communities and societal segments.

Consequently, the liberal and democratic constitution of 1961, and the conservation, the nationalist and anti-liberal constitution of 1982 had one thing in common: they had been designed by bodies and actors that were handpicked by the military elite (Somer, 2016a). These actors and military elite represented various societal segment and dismissed the legitimacy and representation of other segments and communities, depending on their ideological dogmas and convictions. In both scenarios, the Turkish military ensured the legalization of its veto powers and sought to consolidate and institutionalize its right to interfere in mainstream politics. In the aftermath of the 1987 elections, Turkey returned towards free and fair elections and yet, the elected government was unable to enjoy complete autonomy and move away from the influence and dominance of the military elite. The Turkish armed forces enforced their privileges and influence and undertook explicit and implicit interventions to influence mainstream politics and civilian matters. As we examine the transitions of Turkey political structure in light of the five-step model proposed by this paper, we can trace out Turkey's transition towards the consolidation of power amongst one elite group and the systematic exclusion of other groups. In the case of Turkey, the elite group and the inner circle of the ruling party AKP is dominated by traditionalist Ottoman revivalists who seek to bring back the glory of the Ottoman days with a modern democratic structure. As we explore this 'modern democratic structure' with Ottoman undertones, we identify two major flaws that cannot coexist with democratic values: the inability to integrate ethnic minori- 
ties successfully, primarily the Kurdish, into the political system, and the inability to integrate religious and Islamist political groups and actors through their own elected representatives and identities (Somer, 2016a).

Major societal segments only partially experienced many of the democratic transitions that took place in Turkey, and many of these transitions were not applicable on major ethnic communities and regional territories, as witnessed in the case of the Kurds. In simpler words, Turkey's political transition towards authoritarianism can be best understood in terms of territorial, institutional and demographically incomplete changes. During the 1980s, Turkey underwent a partial or incomplete transition towards democratic (Rodriguez et al., 2014). This incomplete transition encouraged further flaws and misleadings in the discourses on the consolidation of democracy throughout the 200s because the democratic rule can only be consolidated within a democratic structure. As we examine the rivalries and high-strung competition between Turkish political parties, the successful completion of free and fair elections, a partially independent and thriving media, we often believe that Turkey has transitioned towards democracy and struggles with obstacles in consolidating democratic ideologies and structures.

As Turkey moves away from democracy and as the economy faces challenges, Erdoğan's AKP party faces rising unpopularity, and it is being increasingly challenged (Somer, 2019), and this culminated in an attempted coup in 2016. As a result of growing challenges to its leadership, there has been a systematic attempt to repress dissent. This has included various types of censorship and intimidation of individuals working in the media as well as an explicit endorsement of violence (Esen \& Gumuscu, 2016; Somer, 2019). For example, police stood aside during an incident in 2015 when vigilante members of the AKP attacked the headquarters of the Hurriyet, a national daily newspaper, for publishing anti-Erdoğan views (Esen \& Gumuscu, 2016). More generally, the party has used state-owned media and regulatory agencies to increase their own control. They have also used the judicial system to harass and intimidate their opponents (Somer, 2019). As a result of the 2016 coup attempt, the government implemented a state of emergency, which is renewed every three months to continue to operate with increased executive power (Esen \& Gumuscu, 2016). The result was to dismiss and suspend more than 100,000 civil servants from office (Freedom House, 2018 ). By the end of 2017 , more than 60,000 people had been arrested in relation to terrorism laws (Freedom House, 2018). Freedom House (2018) reports having evidence of the disappearances of political enemies of the regime, and torture has been commonly reported among those who have been detained. Increasingly, the government has closed over 1500 social organizations and then confiscated the property of those organizations (Freedom House, 2018). The government has also used social media communication to arrest dissidents, which has had the general effect of stifling public political discussion and freedom of expression (Freedom House, 2018). 
Together, these actions have created an elite configuration with no values consensus that has moved away from consensual unity and towards a disunited configuration. Consistent with the prediction of Higley and Burton (2006), this shift towards disunity has occurred at the same time as a shift towards authoritarian governance.

\subsection{Ruling AKP \& Elite Configuration}

The ruling Justice and Development Party (AKP) rose to power towards the end of 2002, and it garnered support from the masses for a range of cultural factors and practical reasons (Çarkoğlu \& Kalaycıŏlu, 2009; Çarkoğlu 2012b). Despite the wide support garnered by the AKP, various factions believed they were being victimized by the revival of "old authoritarianism", which the AKP had pledged to eliminate from governance structures entirely. Research inquiries substantiate that over the years, the AKP has not been successful in dismantling institutions and structures that have allowed old authoritarianism and the reforms and democratic changes undertaken by the AKP government have been ushered in selective spheres (Çarkoğlu, 2012b).

As we explore the five-step model in detail and apply it in the case of Turkey, it becomes clearer that the AKP has enjoyed political support from cultural and Turkish Islamist factions. Over the years, the Turkish Islamists have acted upon the historically institutionalized and ingrained ideological model of "conquering" state institutions and structures as opposed to democratizing these institutions (Çarkoğlu, 2012b). Therefore, researchers have argued that these Islamists elite groups lack the predisposition or ideology to facilitate reforms, and alter the intrusive and complex nature of state institutions to enhance public accountability (Somer, 2016b).

The ideological inclination towards authoritarianism and unaccountability has promoted inequality in the state-society relationship, which has allowed the political elite to work towards hegemony as opposed to working towards building a democratic consensus (Somer, 2016b).

The advent of the AKP into the forefront of Turkey's governance structures has allowed the arrival of a new brand of authoritarianism, which encompasses various concepts and features. As we explore Higley and Burton's (2006) model of elite configuration in the case of Turkey, we identify the existence of a politically disunited elite, and the presence of various agendas that have competed over the years to dominate the governance structure of Turkey. The signs of authoritarianism in Turkey were initially conceptualized as vestiges of the Kemalist regime. Turkey intended to address and eliminate these remnants of authoritarianism during its journey towards consolidating democratic rule. However, Turkey has been largely unsuccessful in this undertaking, and there is a vast lack of clarity amongst scholars on a fundamental question: Can Turkey still be considered a democracy, in light of the criteria of democratic governance? As we explore recent and older research inquiries, the depictions of Turkey's transition 
and governance structure focus on the challenges of consolidating democracy, the authoritarian inclination of the government, elements of competitive authoritarianism, and the advent of delegative democracy. As we explore the influence of competitive authoritarianism in Turkey, we come across a firmly non-democratic regime structure, while other elements can be incorporated into the framework of democratic regimes with "adjectives" (Collier \& Levitsky, 1997; Merkel, 2004; Somer, 2016b).

Turkey began its journey towards democracy with a consensually united elite that sought to increasingly westernized the young Turkish Republic and move away from the traditional Islamist values and lost grandeur of the Ottoman Empire (Somer, 2016b). However, under the rule of the AKP and its predecessors, Turkey evolved into a disunited elite configuration as it worked its way through the 5-step model proposed by this paper.

In recent years, the AKP has altered its religious-sponsorship and descriptions in numerous ways. It started from an Islam-friendly ideology, which developed into an Islamist political agenda, and gradually emerged as authoritarian Islamist ideology. It can be argued that dominant Islamist political and authoritarian Islamist ideologies cannot exist within a democratic structure, nor can they allow democracy to survive. On the other hand, an Islam-friendly ideology can exist and survive within a democratic political structure. As we explore the AKP's new brand of authoritarianism, we see that the incumbent government has made large-scale improvements to the public services and quality amenities provided to the masses. The government has also paved the way for new and improved property rights, alongside initiating massive developmental projects, of which affordable housing is a prominent and note-worthy feature. This is primarily why it can be challenging to differentiate between the inequality and unaccountability promoted by the older welfare regimes, and the welfare activities of the incumbent government as many of their welfare measures appear as attempts to consolidate democracy.

Upon examining more closely, it becomes evident that the new welfare model has given rise to providing charity and public benefits as opposed to providing citizenship rights and democratic policies. Such policies are capable of giving birth to new and more intense forms of social exclusion (Dorlach, 2015). It is important to note that the new model introduced by the AKP government has given birth to a state-society relationship that dispenses benefits and charity on the basis of a particular ideology and political party. This new model has given birth to the belief that state benefits and welfare activities are reliant on political personalities, and political and ideological affiliations as opposed to keeping state institutions impersonal and accountable through legal and institutional rights. This promotes and consolidates authoritarianism by giving the status and influence of "providers" to certain personalities and patrons amongst the political elite, which act as beneficiaries of the public, thereby promoting clientelism to consolidate their power and gains. It also gives birth to a political environ- 
ment where the clients, i.e. the public tends to have less leverage to play one political party against its rival. Consequently, it reduces the opportunities for the opposition parties to challenge and defeat the ruling party in the electoral field.

The new welfare regime has ushered in new authoritarianism through various measures and policies. It has promoted a state-society relationship marred by inequality and lack of accountability, which has, in turn, encouraged the elite members of the ruling party to usher in improvements and developments in a top-down manner as opposed to encouraging fair participation and mobilizing the masses (Dorlach, 2015). It is also important to note that widespread corruption and political clientelism is promoted by an increased emphasis on benefits, services and public amenities instead of highlighting the key welfare and institutional rights of the masses. Moreover, benefits and services are being publicized to maintain focus on the beneficiaries in the political elite as opposed to dispensing them through the relevant informal channels (Eder, 2014).

Empirical evidence reveals that the Turkish government has a history of dispensing welfare benefits and services in a discriminatory manner, in a bid to "reward" its supports and "punish" rivals and opponents (Yoruk, 2012; Aytaç, 2014). Exercising discrimination based on ethnic, cultural and religious affiliations emerges as a dynamic source of breeding inequality, which can tilt the political game in favour of the ruling party. Even if the ruling party and the incumbent government has not purposefully exploited and discriminated factions or misused the welfare services and provisions to promote clientelism, it can be argued that the AKP-led government has reinforced a new brand of authoritarianism through impactful measures (Akkoyunlu \& Izabela, 2016). Such authoritarian measures can create an ambiguity between the government and the ruling party, which tends to make the larger segments of a country believe that their government and the ruling party is indispensable. The AKP-led government has, over the years, outsourced many of the key social welfare responsibilities of the Turkish state to Islamic charities, key political figures, and party organization. It has been practicing a conservative-neoliberal economic model, which be compared to the case of Partido dos Trabalhadores in Brazil, which rose to power with the mandate of eradicating poverty and ushering in economic growth. In Brazil, the ruling party was reliant upon the state institutions to implement an extensive social welfare policy (Akkoyunlu \& Izabela, 2016).

However, the case of Turkey is a striking contrast as the ruling AKP implemented its social welfare policies through various informal and formal channels that were controlled by the party organization, political personalities and key politicians, foundations linked with the AKP and in most cases, the family of President Erdogan. When social welfare, public benefits and assistance is provided directly by the ruling party, it can be argued that the politicians, affiliated organizations and other stakeholders connected with the AKP will be regarded more eminent than the state itself. This is because the beneficiaries-the masses will associate social assistance and welfare with the AKP as opposed to the Tur- 
kish state. This can promote the belief that the continuation of welfare services and assistance depends on the longevity and maintenance of the AKP's rule and prominence. Consequently, this can reduce the level of political competition, and create limitations for the democratic rotation of power and turnover of the political elite, and therefore, it can create limitations for democracy itself. Turkey also presents a governance structure that is largely reliant on faith-based organizations and Sunni Muslim NGOs to outsource welfare and social assistance activities. This outsourcing does not occur due to the incapacities or limitations of the Turkish state in dispensing welfare services, as seen in the case of Lebanon, but in fact; it stems from the ideology and chosen model of governance (Cammett, 2014).

Outsourcing and outright governmental support for religious and faith-based NGOs can also impact the constitution of a state and the membership and engagement of the political community (Cammett, 2014; Somer, 2012). Without dwelling into the level of sectarian or faith-based discrimination promoted by these NGOs, their Sunni Muslim affiliation promotes a perceived dominance and superiority of the majority sectarian-religious identity. This can promote feelings of exclusions amongst other religious and sectarian minorities. The more secular segments of society also tend to feel neglected and excluded. In simpler words, the new welfare apparatus introduced by the AKP government has altered the dynamics of the state-society relationship. There is need for further research to understand the impact of sectarian or religious discrimination on the perceptions of masses with regards to state legitimacy and political power.

As we investigate Turkey's transition towards authoritarianism in light of the five-step model, we understand the dynamics created by the hegemony of one political group, the establishment of a close-knit inner circle to maintain this hegemony and limiting the opportunities and influence of the opposition to control dissent. The case study of Turkey introduces us to the balance of power that exists between various political groups and factions. The AKP has garnered greater influence and success as compared to the Justice Party that rose to immense popularity during the 1960s. The AKP has delivered superior economic performance, and it has also been more successful at eliminating intra-party scuffles to portray a united front. AKP has introduced a more concentrated system of power distribution, and it has promoted a culture of patronage through its distinctive and "diverse techniques" of dispensing social welfare and benefits (Ayan Musil, 2014).

The democratic changes and developments ushered by the AKP have introduced a new political regime in Turkey, with a greater emphasis on shaping the political community and institutions. Scholars who discuss categoric, operational and logical changes in a political system typically refer to governance systems such as competitive authoritarianism or delegative democracy. They take into account the hegemonic power of the AKP and underscore that this no party has been able to encompass such power and influence since the re-establishment of the state, and single-party rule of the Republican People's Party (CHP) from the 
1920s to 1950s (Özbudun, 2011; Somer, 2016a).

Scholars draw attention towards the absence of a clear boundary between the powers of the Turkish state and the ruling party, and they highlight the fragmentation of the already weak institutions of the judiciary and state. The judiciary and state institutions are subjected to a weaker and unequal division of powers and autonomy, while the ruling party enjoys unchecked influence. (Özbudun, 2011; Somer, 2014, 2016b). There is an increased cooptation amongst the business elites, and the state exercises direct or indirect control over the media, dissemination of news and formation of popular opinions. In simpler words, the case study of Turkey reveals an "uneven playing field" where the AKP enjoys a clear dominance over multiparty politics with the odds increasingly tipped in its favour (Somer, 2014; Başkan, 2015; Esen \& Gumuscu, 2016).

\section{Conclusion and Implications}

This article sought to explain Turkey's slide from a democratic into an authoritarian government and towards dictatorship in terms of the elite configurations and processes proposed by elite theorists (Higley \& Burton, 1989, 2006). It is clear that for Turkey, as Higley and Burton (2006) suggest, the recent development of an authoritarian government structure has been accompanied by an increasingly disunited elite. An explanation for the slide towards authoritarianism based on elites is useful when it has other structural factors in place that other theorists have argued support democracy such as a strong economy (until recently) and strong state (Esen \& Gumuscu, 2016).

The five-step model that describes the shift in elite configurations away from democracy and towards autocracy and dictatorship can be summarized:

1) Political success by one group or faction.

2) Establishment of an inner circle and consolidation of power.

3) Replacement of the inner circle with weaker members who can be controlled.

4) Self-isolation of the leader.

5) Government control of opposition and suppression of dissent.

This article further proposed a possible process that explains the change in governance structure-from democracy to authoritarian government-in terms of elite dynamics. It proposes that such a shift can occur as a result of a reduced value consensus caused by the domination of one elite group over another. The process suggested here starts with the legitimate political success of one elite group in a democracy, which is followed by the consolidation of that group's power at the expense of agreed-upon political norms. It may then establish an inner-elite, centered on a single powerful leader, and replace inner-elite members with others who can be controlled, causing isolation of the leader. As that leader faces increasing threats to their leadership-both from other elite groups and from threats within their own elite groups-they increasingly attempt to control the opposition and suppress dissent, further eliminating values consen- 
sus and reducing structural integration. Clearly, the model proposed in this paper does not describe every shift away from democracy towards dictatorship-it is limited in how it can be applied. Still, its utility is in using elite theory to describe and explain a shift in political structures in terms of the interactions between powerful elite individuals. This may be especially relevant given what some are describing as a global move towards authoritarian politics (Freedom House, 2018).

This model for the devolution of democracy has been presented in the context of Turkey, but it could be applied to other contexts. For example, there are currently some concerns that the United States is facing a slide away from democracy, and Nancy Pelosi, the United States House Speaker, has expressed doubt that the current president would cede power in the event that he lost an election (Phillips, 2019). The United States is seen by many as a model of a stable democracy (Higley \& Burton, 2006), and if it were to slide away from democracy, an explanation using a model of how it occurred would be useful. While a comprehensive application of this model to the United States is out of the scope of this paper, the Republican party clearly obtained political victory. This was arguably followed by what could be considered the establishment of an inner circle by the President, Donald Trump, of those close to him (Krol, 2017), which changes regularly (BBC News, 2019). Some also argue that Donald Trump has acted in ways that are uncharacteristic of previous presidents of the United States, and that some of this behavior could undermine the democratic norms (or values consensus) around what appropriate political behavior is in the United States (Lieberman et al., 2019). Thus, a cursory glance provides some reason to suspect this model could be applied to the context in the United States. Similarly, such a model could be useful in describing the move away from democracy that is occurring in several South Eastern European countries such as Serbia, Macedonia, and Montenegro (Džankić, 2018; Keil, 2018). Such a model is proposed here, with a focus on the explanation of the role of elite dynamics; and it is hoped that the elite model could be a useful addition to Higley and Burton's elite theory.

\section{Conflicts of Interest}

The author declares no conflicts of interest regarding the publication of this paper.

\section{References}

Akkoyunlu, K., \& Izabela, C. (2016). Brazil and Turkey between Absolute Power and Democracy. Birikim.

https://www.birikimdergisi.com/guncel/7716/mutlak-iktidar-ve-demokrasi-arasinda-br ezilya-ve-turkiye\#.V3of5Lh97bI

Ant, O., \& Hacaoglu, S. (2018). Erdogan Expands Clout over the Central Bank, as He Promised. Bloomberg, July 10, 2018.

https://www.bloomberg.com/news/articles/2018-07-10/erdogan-gives-himself-power-t o-appoint-central-bank-governor

Atacan, F. (2005). Explaining Religious Politics at the Crossroad: AKP-SP. Turkish Studies, 6, 187-199. https://doi.org/10.1080/14683840500119510 
Ayan Musil, P. (2014). Emergence of a Dominant Party System after Multipartyism: Theoretical Implications from the Case of the AKP in Turkey. South European Society and Politics, 20, 71-92. https://doi.org/10.1080/13608746.2014.968981

Aytaç, S. E. (2014). Distributive Politics in a Multiparty System the Conditional Cash Transfer Program in Turkey. Comparative Political Studies, 47, 1211-1237. https://doi.org/10.1177/0010414013495357

Barr, R. R. (2009). Populists, Outsiders and Anti-Establishment Politics. Party Politics, 15, 29-48. https://doi.org/10.1177/1354068808097890

Başkan, B. (2015). Turkey's Islamists: Accidental Democrats. Review of Middle East Studies, 49, 38-47. https://doi.org/10.1017/rms.2015.48

BBC News (2019). The White House Revolving Door: Who's Gone? BBC News, July 29, 2019. https://www.bbc.com/news/world-us-canada-39826934

Best, H., \& Higley, J. (2018). The Palgrave Handbook of Political Elites. London: Palgrave Macmillan. https://doi.org/10.1057/978-1-137-51904-7

Bian, Y., Shu, X., \& Logan, J. R. (2001). Communist Party Membership and Regime Dynamics in China. Social Forces, 79, 805-841. https://doi.org/10.1353/sof.2001.0006

Bourdieu, P. (1984). Distinction: A Social Critique of the Judgement of Taste. Cambridge, MA: Harvard University Press.

Bourdieu, P. (1986). The Forms of Capital. In J. G. Richardson (Ed.), Handbook of Theory and Research for the Sociology of Education (pp. 241-258). New York: Greenwood.

Cagaptay, S. (2017). The New Sultan: Erdogan and the Crisis of Modern Turkey. London: I.B. Tauris. https://doi.org/10.5040/9781350988972

Cagaptay, S. (2018). The New Sultan and the Crisis of Modern Turkey. Italian Journal of International Affairs, 53, 1-15. https://doi.org/10.1080/03932729.2018.1503857

Cammett, M. (2014). Compassionate Communalism: Welfare and Sectarianism in Lebanon. Ithaca, NY: Cornell University Press. https://doi.org/10.7591/9780801470332

Çarkoğlu, A. (2012a). Economic Evaluations vs Ideology: Diagnosing the Sources of Electoral Change in Turkey, 2002-2011. Electoral Studies, 31, 513-521.

https://doi.org/10.1016/j.electstud.2012.02.005

Çarkoğlu, A. (2012b). Voting Behaviour in Turkey. In M. Heper, \& S. Sayarı (Eds.), Handbook of Modern Turkey (pp. 160-170). New York: Routledge.

Çarkoğlu, A., \& Kalaycıoğlu, E. (2009). The Rising Tide of Conservatism in Turkey. New York: Palgrave Macmillan. https://doi.org/10.1057/9780230621534

Casper, G. (1995). Fragile Democracies: The Legacies of Authoritarian Rule. Pittsburgh, PA: University of Pittsburgh Press.

Collier, D., \& Levitsky, S. (1997). Democracy with Adjectives: Conceptual Innovation in Comparative Research. World Politics, 49, 430-451.

https://doi.org/10.1353/wp.1997.0009

Congressional Research Service (2018). Turkey's Currency Crisis. https://fas.org/sgp/crs/mideast/IF10957.pdf

Coşar, S., \& Özman, A. (2004). Centre-Right Politics in Turkey after the November 2002 General Election: Neo-Liberalism with a Muslim Face. Contemporary Politics, 10, 57-74. https://doi.org/10.1080/13569770410001701233

Diamond, L. (2015). Facing Up to the Democratic Recession. Journal of Democracy, 26, 141-155. https://doi.org/10.1353/jod.2015.0009 
Domhoff, G. W. (2017). The Power Elite and the State: How Policy Is Made in America. New York: Routledge. https://doi.org/10.4324/9781315134086

Dorlach, T. (2015). The Prospects of Egalitarian Capitalism in the Global South: Turkish Social Neoliberalism in Comparative Perspective. Economy and Society, 44, 519-544. https://doi.org/10.1080/03085147.2015.1090736

Džankić, J. (2018). Capturing Contested States: Structural Mechanisms of Power Reproduction in Bosnia and Herzegovina, Macedonia and Montenegro. Southeastern Europe, 42, 83-106. https://doi.org/10.1163/18763332-04201005

Eder, M. (2014). Deepening Neo-Liberalization and a Changing Welfare Regime in Turkey: Mutations of Populist, “Sub-Optimal” Democracy on Turkey's Democratization Process (pp. 195-220). New York: Routledge.

Esen, B., \& Gumuscu, S. (2016). Rising Competitive Authoritarianism in Turkey. Third World Quarterly, 37, 1581-1606. https://doi.org/10.1080/01436597.2015.1135732

Esen, B., \& Gumuscu, S. (2017). Turkey: How the Coup Failed. Journal of Democracy, 28, 59-73. https://doi.org/10.1353/jod.2017.0006

Fanack (2018). Like Father, like Son-in-Law: Meet Turkey’s Ruling Family. https://fanack.com/turkey/faces/berat-albayrak

Freedom House (2018). Turkey. Freedom in the World 2018. Washington DC: Freedom House.

Gall, C. (2019). Erdogan's Party Is Deeply Divided by Push to Redo Istanbul Election. The New York Times.

https://www.nytimes.com/2019/04/25/world/europe/turkey-erdogan-istanbul-election. $\underline{\mathrm{html}}$

Gerschewski, J. (2013). The Three Pillars of Stability: Legitimation, Repression, and Cooptation in Autocratic Regimes. Democratization, 20, 13-38.

https://doi.org/10.1080/13510347.2013.738860

Hadiz, V. R. (2016). Islamic Populism in Indonesia and the Middle East. Cambridge: Cambridge University Press. https://doi.org/10.1017/CBO9781316402382

Heilbron, J., Bühlmann, F., Hjellbrekke, J., Korsnes, O., \& Savage, M. (2017). Introduction. In O. Korsnes, J. Heilbron, J. Hjellbrekke, F. Bühlmann, \& M. Savage (Eds.), New Directions in Elite Studies (pp. 1-28). London: Routledge. https://doi.org/10.4324/9781315163796-1

Herzog, D. (1982). Politische Führungsgruppe. Darmstadt: Wissenschaftliche Buchgesellschaft, $23 \mathrm{f}$.

Higley, J. (2009). Elite Theory and Elite. In K. T. Leicht, \& J. C. Jenkins (Eds.), Handbook of Politics: State and Society in Global Perspective (pp. 161-176). New York: Springer Science and Business Media. https://doi.org/10.1007/978-0-387-68930-2 9

Higley, J. (2018a). Continuities and Discontinuities in Elite Theory. In H. Best, \& J. Higley (Eds.), The Palgrave Handbook of Political Elites (pp. 25-40). London: Palgrave Macmillan. https://doi.org/10.1057/978-1-137-51904-7_4

Higley, J. (2018b). Patterns of Political Elites. In H. Best, \& J. Higley (Eds.), The Palgrave Handbook of Political Elites (pp. 155-160). London: Palgrave Macmillan. https://doi.org/10.1057/978-1-137-51904-7 12

Higley, J., \& Burton, M. G. (1989). The Elite Variable in Democratic Transitions and Breakdowns. American Sociological Review, 54, 17-32.

https://doi.org/10.2307/2095659 
Higley, J., \& Burton, M. G. (2006). Elite Foundations of Liberal Democracy. Lanham, MD: Rowman and Littlefield.

Horizon (2018). The Growing Irrelevance of Erdogan's Advisory Circle. Horizon, April. http://hcaccess.com/insights/the-growing-irrelevance-of-erdogans-advisory-circle

Kahn, S. R. (2012). The Sociology of Elites. Annual Review of Sociology, 38, 361-377. https://doi.org/10.1146/annurev-soc-071811-145542

Keil, S. (2018). The Business of State Capture and the Rise of Authoritarianism in Kosovo, Macedonia, Montenegro, and Serbia. Southeastern Europe, 42, 59-82. https://doi.org/10.1163/18763332-04201004

Keller, S. (1963). Beyond the Ruling Class: Strategic Elites in Modern Society. New York: Random House.

Kendall-Taylor, A., Frantz, E., \& Wright, J. (2017). The Global Rise of Personalized Politics: It's Not Just Dictators Anymore. The Washington Quarterly, 40, 7-19. https://doi.org/10.1080/0163660X.2017.1302735

Kinzer, C. (2008). Crescent and Star: Turkey between Two Worlds. New York: Farrar Straus and Giroux.

Krol, A. (2017). Donald Trump's Inner Circle: Who Are the Key Figures Driving the President's Policy Agenda? The Telegraph, February 2, 2017.

https://www.telegraph.co.uk/news/0/donald-trumps-inner-circle-key-figuresdriving-presidents-policy

Lazic, M., \& Pesic, J. (2018). Making a New Consensual Elite in Serbia. Corvinus Journal of Sociology and Social Policy, 8, 195-219. https://doi.org/10.14267/cjssp.2017.3S.09

Levitsky, S., \& Way, L. A. (2010a). Competitive Authoritarianism: Hybrid Regimes after the Cold War. Cambridge: Cambridge University Press. https://doi.org/10.1017/CBO9780511781353

Levitsky, S., \& Way, L. A. (2010b). Why Democracy Needs a Level Playing Field. Journal of Democracy, 21, 57-68. https://doi.org/10.1353/jod.0.0148

Lewis, P. H. (2002). Latin Fascist Elites: The Mussolini, Franco, and Salazar Regimes. Westport, CT: Praeger.

Lieberman, R. C., Mettler, S., Pepinsky, T. B., Roberts, K. M., \& Valelly, R. (2019). The Trump Presidency and American Democracy: A Historical and Comparative Analysis. Perspectives on Politics, 17, 470-479. https://doi.org/10.1017/S1537592718003286

Linz, J. J. (1990). The Perils of Presidentialism. Journal of Democracy, 1, 51-69.

Linz, J. J. (2000). Totalitarian and Authoritarian Regimes. Boulder, CO: Lynne Rienner Publishers, Inc.

Linz, J. J., \& Stepan, A. (1996). Problems of Democratic Transition and Consolidation: Southern Europe, South America, and Post-Communist Europe. Baltimore, MD: Johns Hopkins University Press.

Lopez, M. (2013). Elite Theory. Sociopedia.isa, 1-12. ISSN: 2056-8460.

MacDonald, A. (2018). Erdogan's Inner Circle Spar over the Future of the Turkish Economy. Middle East Eye, 4th July.

https://www.middleeasteye.net/news/erdogans-inner-circle-spar-over-future-t urkish-economy

Mahdavi, P., \& Ishiyama, J. (2017). Dynamics of the Inner Elite in Dictatorships: Evidence from North Korea. Comparative Politics, 52, 221-249.

https://doi.org/10.5129/001041520X15652680065751 
Merkel, W. (2004). Embedded and Defective Democracies. Democratization, 11, 33-58. https://doi.org/10.1080/13510340412331304598

Michels, R. (1962). Political Parties: A Sociological Study of the Oligarchical Tendencies in Modern Democracy. New York: Free Press.

Mills, S. R. (1956). The Power Elite. Oxford: Oxford University Press.

Mosca, G. (1960). The Ruling Class. New York: McGraw-Hill Book Company.

Müftüler-Baç, M., \& Fuat Keyman, E. (2012). The Era of Dominant-Party Politics. Journal of Democracy, 23, 85-99. https://doi.org/10.1353/jod.2012.0000

Musil, P. (2014). HükümetSistemleri: Başkanlık Sistemive Parlamenter Sistem (pp. 207223). Istanbul: S. Sayarı, HD Bilgin, İstanbul Bilgi ÜniversitesiYayınları.

Önis, Z. (2015). Monopolising the Centre: The AKP and the Uncertain Path of Turkish Democracy. The International Spectator, 50, 22-41. https://doi.org/10.1080/03932729.2015.1015335

Oyat, C. (2018). The End of Boom and the Political Economy of Turkey's Crisis. Policy Brief.

https://gala.gre.ac.uk/id/eprint/21403/13/21403\%20OYVAT The End of Bo om_and_the_Political_Economy\%20of_Turkey\%E2\%80\%99s_Crisis_2018.pdf

Özbudun, E. (2011). Authoritarian Regimes, Electoral Democracies and Turkey. İstanbul: Bilgi Üniversitesi Yayınları.

Özbudun, E. (2014). AKP at the Crossroads: Erdoğan's Majoritarian Drift. South European Society and Politics, 19, 155-167. https://doi.org/10.1080/13608746.2014.920571

Özbudun, E. (2015). Turkey's Judiciary and the Drift toward Competitive Authoritarianism. The International Spectator, 50, 42-55. https://doi.org/10.1080/03932729.2015.1020651

Pareto, V. (1935). The Mind and Society. New York: Harcourt, Brace.

Pérez-Liñán, A., \& Mainwaring, S. (2013). Regime Legacies and Levels of Democracy: Evidence from Latin America. Comparative Politics, 45, 379-397. https://doi.org/10.5129/001041513X13815259182785

Phillips, A. (2019). Nancy Pelosi Is Worried Trump Won't Give Up Power If He Loses in 2020. He Just Underscored Why. The Washington Post, May 6, 2019.

https://www.washingtonpost.com/politics/2019/05/06/nancy-pelosi-is-worried -trump-wont-give-up-power-he-just-underscored-why/?noredirect=onandut $\underline{m \text { term }}=. \mathrm{cfb} 2 \mathrm{dcfd} 2400$

Picarella, L. (2018). Democratic Deviations and Constitutional Changes: The Case of Turkey. Academic Journal of Interdisciplinary Studies, 7, 9-16. https://doi.org/10.2478/ajis-2018-0041

Rodriguez, C., et al. (2014). Democratization Processes in Defective Democracies: The Case of Turkey: Turkey's Democratization Process. Rutledge, New York.

Schanzer, J., Erdemir, A., \& Tahiroglu, M. (2019). The Prospect of U.S. Sanctions Exacerbates Turkey's Political and Economic Risks. https://www.fdd.org/analysis/memos/2019/04/01/the-prospect-of-u-s-sanction s-exacerbates-turkeys-political-and-economic-risks

Shorten, R. (2012). Modernism and Totalitarianism. London: Palgrave Macmillan. https://doi.org/10.1057/9781137284372

Seufert, G. (2014). Erdoğan's "New Turkey": Restoring the Authoritarian State in the Name 
of Democracy. Berlin: German Institute for International and Security Affairs.

Somer, M. (2012). The Janus-Faced Relation of Religious Non-State Actors and Human Security: Islamic and Secular Values in Turkey (pp. 30-47). Oxford: Oxford University Press. https://doi.org/10.1093/acprof:oso/9780199827732.003.0003

Somer, M. (2014). Moderation of Religious and Secular Politics, a Country's "Centre" and Democratization. Democratization, 21, 244-267. https://doi.org/10.1080/13510347.2012.732069

Somer, M. (2016a). Return to Point Zero: From Nation-State to State-Nation, the Three Dilemmas of the Turkish and Kurdish Question. Istanbul: Koç Üniversitesi Yayınları.

Somer, M. (2016b). Understanding Turkey's Democratic Breakdown: Old vs. New and Indigenous vs. Global Authoritarianism. Journal of Southeast European and Black Sea, 16, 481-503. https://doi.org/10.1080/14683857.2016.1246548

Somer, M. (2019). Turkey: The Slippery Slope from Reformist to Revolutionary Polarization and Democratic Breakdown. The Annals of the American Academy of Political and Social Sciences, 681, 42-61. https://doi.org/10.1177/0002716218818056

Tang, M., Huhe, N., \& Zhou, Q. (2015). Contingent Democratization: When Do Economic Crises Matter? British Journal of Political Science, 47, 71-90. https://doi.org/10.1017/S0007123415000095

Taskinsoy, J. (2019). A Delicate Moment in Turkey's Economic Transition: Can Turkey Survive Mounting Economic Problems without the IMF's Bailout Package? https://doi.org/10.2139/ssrn.3408520

Turk, H. B. (2014). Muktedir: Türk Să̆ Geleneği ve Recep Tayyip Erdoğan. Istanbul: İletişim.

Urban, M. (1989). Centralization and Elite Circulation in a Soviet Republic. The British Journal of Political Science, 19, 1-23. https://doi.org/10.1017/S0007123400005299

Wedel, J. R. (2009). Shadow Elite: How the World's New Power Brokers Undermine Democracy, Government, and the Free Market. New York: Basic Books.

Wedel, J. R. (2017). From Power Elites to Influence Elites: Resetting Elite Studies for the 21st Century. Theory, Culture and Society, 34, 153-178. https://doi.org/10.1177/0263276417715311

Yavuz, M. H. (2009). Secularism and Muslim Democracy in Turkey. Cambridge: Cambridge University Press. https://doi.org/10.1017/CBO9780511815089

Yoruk, E. (2012). Welfare Provision as Political Containment: The Politics of Social Assistance and the Kurdish Conflict in Turkey. Politics \& Society, 40, 517-547.

https://doi.org/10.1177/0032329212461130 